\title{
Elaboration of mayonnaises containing landrace common bean flour as a partial egg yolk substitute
}

\author{
Jamila dos Santos Alves ${ }^{1 *}$ (iD) Angela Souza Rodrigues ${ }^{1}$ iD Karine Inês Bolson Moro ${ }^{1}$ (iD) \\ Caroline Pagnossim Boeira ${ }^{1}$ iD Augusto Tasch Holkem ${ }^{2}$ iD Isabel Roggia $^{3}$ iD \\ Patrícia Medianeira Grigoletto Londero ${ }^{1}$ iD Claudia Severo da Rosa $^{1}$ iD
}

${ }^{1}$ Programa de Pós-Graduação em Ciência e Tecnologia dos Alimentos, Universidade Federal de Santa Maria (UFSM), 97105-900, Santa Maria, RS, Brasil. E-mail: alves.jamila@outlook.com. *Corresponding author.

${ }^{2}$ Departamento de Engenharia de Alimentos, Faculdade de Zootecnia e Engenharia de Alimentos, Universidade de São Paulo (USP), São Paulo, SP, Brasil.

${ }^{3}$ Programa de Pós-Graduação em Nanociências, Laboratório de Nanotecnologia, Universidade Franciscana (UFN), Santa Maria, RS, Brasil.

ABSTRACT: Mayonnaise is one of the most consumed sauces in the world and beans have great technological functional properties. As a result, beans can be used in the production of mayonnaise as a partial substitute for egg yolk (EY), reducing cholesterol content, post-harvest losses and adding nutritional value to mayonnaise. This study evaluated the effect of the partial replacement of EY by landrace common bean flour (LCBF) on the parameters of rheology, chemical and physical composition of mayonnaise. Four mayonnaise formulations were developed: $T 1$ (Standard), 100\% egg yolk (EY); T2, 75\% EY and 25\% FFC; T3, 50\% EY and 50\% LCBF; T4, 25\% EY and 75\% LCBF. The partial substitution of EY for LCBF increased the protein content, decreased the content of lipids and cholesterol. The obtained mayonnaise continued to exhibit pseudoplastic behaviour, being a characteristic of non-Newtonian fluid. The water activity of the mayonnaise was not changed with the replacement of the partial of the egg yolk and the pH decreased during the storage. The substitution of EY can be carried out in quantities of up to $50 \%$ without prejudice to mayonnaise, the formulation with $50 \%$ substitution presented the best viscosity and remained stable, similar to the standard mayonnaise.

Key words: mayonnaise, cholesterol, vegetable protein, rheology.

Elaboração de maionese contendo farinha de feijão crioulo como substituto parcial da gema de ovo

RESUMO: A maionese é um dos molhos mais consumidos no mundo e o feijão apresenta ótimas propriedades funcionais tecnológicas. Com isso, o feijão pode ser usado na produção de maionese como substituto parcial da gema de ovo diminuindo o teor de colesterol, perdas pós colheita e agregando valor nutricional a maionese. Este estudo avaliou o efeito da substituição parcial da gema de ovo pela farinha de feijão crioulo (FFC) sobre os parâmetros de reologia, composição química e fisica da maionese. Foram desenvolvidas quatro formulações de maionese: $T 1$ (Padrão), 100\% de gema de ovo (GO); T2, 75\% GO e 25\% FFC; T3, 50\% GO e 50\% FFC; T4, 25\% GO e 75\% FFC. A substituição parcial da GO pela FFC aumentou o teor proteíco, diminuiu o conteúdo de lipídios e colesterol. A maionese obtida continuou exibindo comportamento pseudoplástico, sendo uma característica do fluido não newtoniano. A atividade de água das maioneses não foi alterada com a substituição parcial da gema de ovo e o pH diminuiu ao longo do armazenamento. A substituição da GO pode ser realizada em quantidades de até $50 \%$ sem prejuizo das maioneses, a formulação com $50 \%$ de substituição apresentou a melhor viscosidade e se manteve estável, semelhante à maionese padrão.

Palavras-chave: maionese, colesterol, proteina vegetal, reologia.

\section{INTRODUCTION}

The common bean (Phaseolus vulgaris L.), which is a very important legume in the diet of Brazilians, is a food that is low in lipids and rich in protein, fiber, complex carbohydrates, bioactive compounds, B vitamins and minerals (AGUILERA et al., 2011). Besides being a source of essential nutrients, beans are now receiving increasing attention as a potential functional food; their consumption has been linked with decreased risk of cardiovascular disease, diabetes, obesity, cancer and diseases of the digestive tract (CARDADOR-MARTÍNEZ et al., 2002). The flour produced from beans can be a way of ingesting this legume and some studies have investigated the use of this flour in different types of products (LONDERO et al., 2015; RAMÍREZJIMÉNEZ et al., 2018). However, there are few studies regarding the use of flour made from landrace common bean cultivars in the development of 
products. Landrace common beans can be defined as bean genotypes in use by farmers, which can be generated from natural crosses, and which have not undergone the process of genetic improvement (PEREIRA et al., 2011).

Mayonnaise is a type of oil-in-water emulsion in semi-solid form and it is composed of about $70-80 \%$ vegetable oil, egg yolk, vinegar and spices (mainly mustard) (NIKZADE et al., 2012). According to Brazilian legislation, mayonnaise is defined as a creamy product in the form of stable oilin-water emulsion, which is prepared from vegetable oil(s), water and eggs. Other ingredients can be added provided they do not characterize the product. The legislation also states that the product must be acidified (BRASIL, 2005).

Healthy people $(70 \%)$ can consume one egg a day but should always be aware of the total daily cholesterol intake limit, which should not exceed $300 \mathrm{mg}$ (according to the American Heart Association (AHA) recommendation, followed in Brazil) (PIZZOLANTE, 2012). It is known that the egg today is no longer a food villain, but care should be taken with the amount.

The use of proteins derived from vegetables to stabilize food has some advantages; they do not contribute to an increase in cholesterol and they are technologically easier to handle (RISCARDO et al., 2003). There are literature reports of mayonnaises prepared with different sources of vegetable-derived protein (NIKZADE et al., 2012; RAHBARI et al., 2014) but none using common bean flour. Recent studies have shown that flour made from pulses has good technological and functional characteristics such as water holding capacity, and oil and emulsifying properties (WANI et al., 2013, ALVES et al., 2019).

Given the above, the objective of this study was to evaluate the effect of the partial replacement of EY by LCBF on the parameters of rheology, and chemical and physical composition in mayonnaise.

\section{MATERIALS AND METHODS}

The "Carioca" variety landrace common beans (LCBF) were obtained from the "Association of Landrace Seed Keepers of Ibarama" in the mountain region of the Rio Grande do Sul. To prepare the flour, the dirt was initially manually removed from the beans. The beans were ground in a refrigerated micro mill (Marconi ${ }^{\circledR}$, MA-630 model), which produced the flour. The flour was then standardized in a 60 mesh $(0.25 \mathrm{~mm})$ granulometer. The flours were subsequently stored in low-density polyethylene bags under refrigeration $\left(4^{\circ} \mathrm{C}\right)$ (ALVES et al., 2019). The formulation of the mayonnaises followed the methodology described by NIKZADE et al. (2012), with modifications. A standard formulation was prepared (T1) (100\% egg yolk), the recipe contained the following ingredients: Oil $60.00 \mathrm{~g}$, water 18.65 $\mathrm{g}$, egg yolk (pasteurized and refrigerated) $10.00 \mathrm{~g}$, vinegar $7.50 \mathrm{~g}$, salt $1.50 \mathrm{~g}$, sugar $1.10 \mathrm{~g}$, powdered mustard $0.45 \mathrm{~g}$, white pepper $0.36 \mathrm{~g}$, saffron 0.13 $\mathrm{g}$, xanthan gum $0.10 \mathrm{~g}$, guar gum $0.10 \mathrm{~g}$, potassium sorbate $0.10 \mathrm{~g}$, BHT $0.01 \mathrm{~g}$ and formulations where egg yolk (EY) was replaced by landrace common bean flour (LCBF) in different ratios (T2: $25 \%$ LCBF (2.50 g) and 75\% EY (7.50 g); T3: 50\% LCBF $(5.00 \mathrm{~g})$ and $50 \% \mathrm{EY}(5.00 \mathrm{~g})$; and T4: 75\% LCBF $(7.50 \mathrm{~g})$ and $25 \% \mathrm{EY}(2.50 \mathrm{~g}))$. With the aid of a mixer, the egg yolk and/or common bean flour and water were mixed together, followed by the addition of the other ingredients. Soon afterwards, a small amount of soybean oil was added and mixed for five minutes and then the vinegar was gradually added. Subsequently, the main amount of the soybean oil was slowly added during five minutes. After the preparation of the mayonnaises they were placed in polyethylene terephthalate (PET) containers and stored in a refrigerator at $4{ }^{\circ} \mathrm{C}$.

Moisture, ash, lipids and crude protein were determined according to the Association of Official Analytical Chemists - AOAC (2005). The total carbohydrates were obtained by difference from the other fractions. The total dietary fiber content was theoretically calculated from the total dietary fiber content reported in the LCBF. The cholesterol content was determined by the enzymatic method described by SALDANHA et al. (2004). A -PP Cholesterol kit (Gold Analisa Diagnóstica, Mg, Brazil) was used.

The microstructures of the samples were determined on day 0 of storage at $4{ }^{\circ} \mathrm{C}$ using an optical microscope (Carl Zeiss Axio Scope.A1, Oberkochen, Germany), which was equipped with an Axio Cam MRc digital camera (Carl Zeiss).

The rheology of the mayonnaises was performed using a rotational viscometer (Brookfield, RVDV II+) equipped with a C93 spindle at a round shear rate (ascending curve) and back shear rate (downward curve) that varied from 0.5 to $100 \mathrm{~s}^{-1}$. All the tests were carried out at $25^{\circ} \mathrm{C} \pm 1{ }^{\circ} \mathrm{C}$ and before starting any measurements, the sample was allowed to rest for at least $15 \mathrm{~min}$. For the preparation of the rheogram, the shear stress was calculated using Equation 1.

$\tau=\eta_{a p}(\gamma)$

Where $\tau$ is $\tau$ the shear stress, $\eta_{a p}$ is the apparent viscosity and $\gamma$ is the shear rate. 
The rheogram was obtained on day 0 of storage of the mayonnaises. The data relating to apparent viscosity at days 0 and 30 of storage and the parameters of consistency index $(K)$ and fluid behaviour index (dimensionless) $n$, were observed during days $0,7,14,21$ and 30 of storage.

The $\mathrm{pH}$ was measured at $0,7,14,21$, and 30 days of storage at room temperature using a digital potentiometer. The water activity (Aw) content was determined using previously calibrated Aqualab $^{\circledR}$ equipment on days $0,7,14,21$ and 30 . The colour tests were performed using a colorimetric spectrophotometer (Minolta ${ }^{\circledR}$ CR-310) with D65 illuminant on days 0, 7, 14, 21 and 30. The CIE color system $L^{*} a^{*} b^{*}$ (CIELAB) was used. The assessment of stability (S) followed the methodology described by MUN et al. (2009).

The data were submitted to analyse the variance and compare means using the Tukey test at $5 \%$ level of significance. Results were analyzed using Statistica $^{\circledR}$ software version 8.0 (Statsoft Inc., Tulsa, OK, USA).

\section{RESULTS AND DISCUSSION}

The moisture values ranged from 22.36 (T4) to $29.91 \%$ (T1) table 1 . There was no significant difference between $\mathrm{T} 1$ and $\mathrm{T} 2$; however, T1 differed from $\mathrm{T} 3$ and $\mathrm{T} 4$. This fact can be explained by the higher concentration of LCBF in these treatments. Similarly to the findings of the present study, ELBOSTANY et al. (2011) reported a decrease in moisture content in mayonnaise when pureed mashed potatoes were added.

The ash content ranged from 3.87 to $4.20 \%$ and there was no significant difference between the treatments. The protein content increased in line with increases in the amount of LCBF in the mayonnaises.

The lipid levels decreased as the level of LCBF increased. The largest reduction was obtained for T4 (8.7\%). RAHBARI et al. (2014) reported higher values than those found in this study when they produced mayonnaise with low cholesterol content and different concentrations of wheat germ protein isolate to replace egg yolk (66.38 to $68.17 \%$ ).

The total carbohydrates increased as the content of bean flour increased. In the study, the total dietary fiber content increased as the amount of LCBF increased in the mayonnaises. This result was important because mayonnaise does not contain dietary fiber. El-Bostany et al. (2011) reported dietary fiber values ranging from 0.26 to $1.14 \%$ in mayonnaise with added powdered mashed potatoes; lower values than those found in this study.
The cholesterol content reported in the mayonnaises in the study is shown in table 1 . The values ranged from 168.63 (T1) to $141.60 \mathrm{mg} / 100 \mathrm{~g}$. (T4). There were significant differences between the treatments and the cholesterol content decreased in line with increases in the LCBF content Treatment 4 had a $16 \%$ reduction in cholesterol.

Figure 1A shows that the control mayonnaise had a denser structure, with symmetrical spherical drops. This was due to the fact that egg yolk is a good emulsifying agent. The replacement of egg yolk by LCBF drastically affected the structure of the mayonnaise. The amount of bean starch granules increased in line with increases in the replacement of egg yolk by LCBF. MA et al. (2015) also observed an increased number of starch granules in samples of salad dressing that were supplemented with larger quantities of legume flours.

The study of rheological properties in mayonnaise is one of the main factors that influence its quality, not only to the technological process (mixing, pumping), transport and storage of mayonnaise but also to its acceptance among consumers (JUSZCZAK et al., 2003). Through the analysis of the rheological characteristics of mayonnaises (Figure 1B), it was found that for certain shear rates, different shear stress values were obtained, hence no proportionality between the data was typical of non-Newtonian behaviour (IBARZ \& BARBOSA-CÁNOVAS, 2011).

Table 2 shows that all the formulations presented pseudoplastic behaviour because they presented flow behaviour index $(n)$ less than 1, which is the value that shows deviation from Newtonian behaviour. Pseudoplastic behaviour has been reported in previous studies with different kinds of mayonnaises (MA \& BARBOSACÁNOVAS, 1995; WORRASINCHAI et al, 2006). All samples exhibited thixotropic characteristics due to differences in the tension and viscosity of the curves of the ascending and descending rates (Figure 1B). According to Mathias et al. (2013), as well as being dependent on the rate, pseudoplastic fluids can also be thixotropic depending on the shear time.

According to the apparent viscosity readings, it is observed that the viscosity decreased with the increase of the shear rate. According to MCCLEMENTS (2016) the droplets may become deformed and disrupted eventually as the shear rate increase, contributing to the reduction of viscosity. Analyzing the start (day 0) and the end (day 30) of storage, there was a decrease in the 
values for all the mayonnaise samples. T3 showed higher viscosity for day 0 compared to the other treatments; however, T3 did not differ significantly when compared to $\mathrm{T} 1$. This behaviour can be explained by the fact that the LCBF had good emulsifying activity $(42,67 \pm 0,41)$ ALVES et al. (2019) with standard-like viscosity.

In this study there was a decrease in the consistency index $(K)$ of all the samples during the storage period, with significant difference when they were compared with each other (Table 2). Treatment T3 showed the highest $K$ values, though it was not significantly different from $\mathrm{T} 1$ on day 0 of storage. The $K$ parameter is related to the viscosity of a product, so the data related to the consistency index corroborated the apparent viscosity (Figure 1C), which showed a decrease in the values on days 0 and 30 of storage.

Results in figure 1D showed that there was a decrease in $\mathrm{pH}$ for all the evaluated treatments during storage. A similar situation was reported by KISHK \&

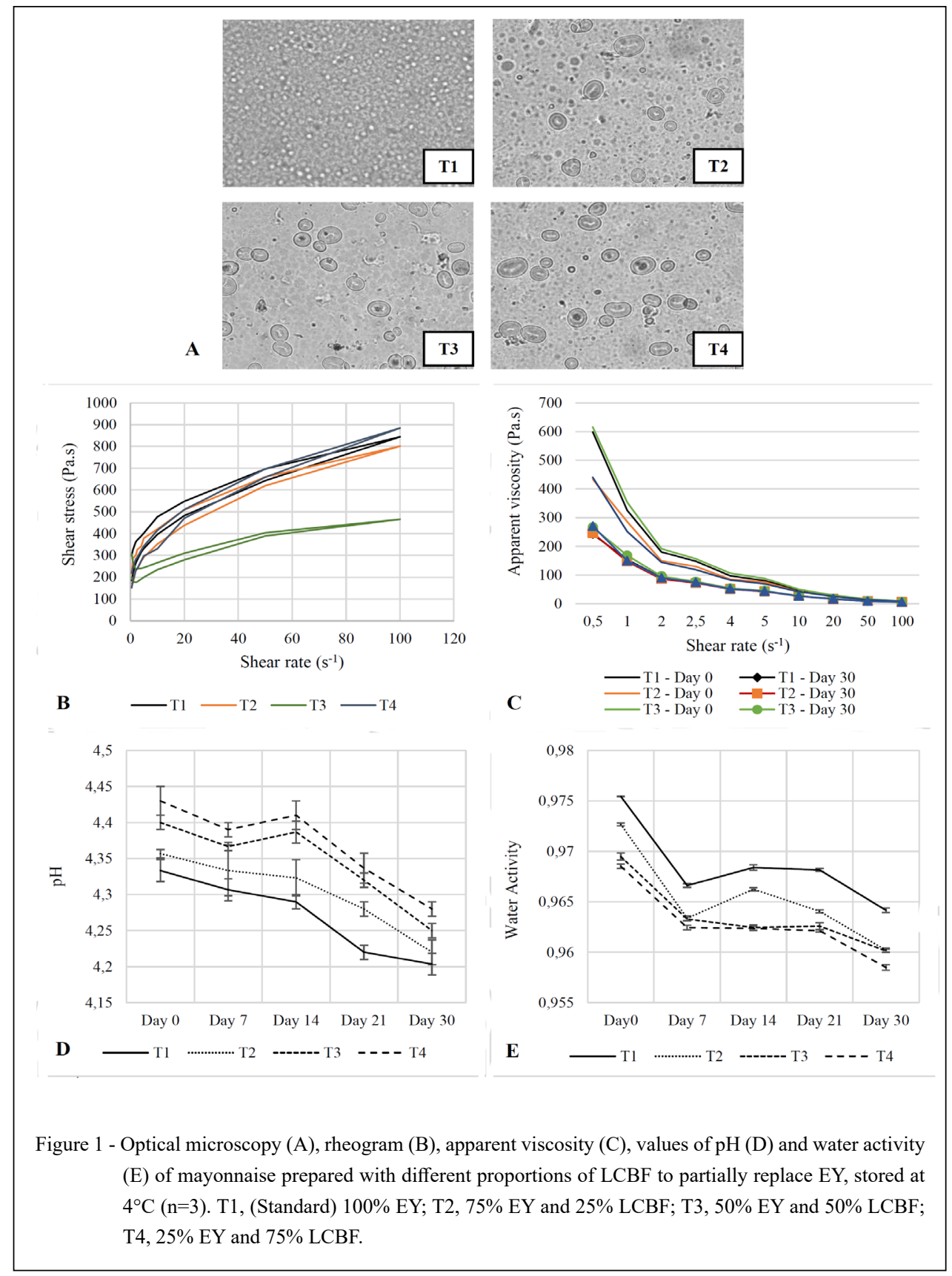

Ciência Rural, v.51, n.9, 2021. 
Table 1- Chemical composition and cholesterol of mayonnaise prepared with different proportions of LCBF to partially replace EY, stored at $4^{\circ} \mathrm{C}$.

\begin{tabular}{|c|c|c|c|c|c|}
\hline Constituents & LCBF* & $\mathrm{T} 1$ & $\mathrm{~T} 2$ & $\mathrm{~T} 3$ & $\mathrm{~T} 4$ \\
\hline Moisture (\%) & $11.60 \pm 0.46$ & $29.91 \pm 0.01^{\mathrm{a}}$ & $28.4 \pm 1.14^{\mathrm{ab}}$ & $27.2 \pm 0.47^{b}$ & $22.36 \pm 0.07^{b}$ \\
\hline Ash (\%) & $5.08 \pm 0.02$ & $4.12 \pm 0.10^{\mathrm{a}}$ & $4.19 \pm 0.26^{\mathrm{a}}$ & $4.20 \pm 0.15^{\mathrm{a}}$ & $3.87 \pm 0.01^{\mathrm{a}}$ \\
\hline Protein (\%) & $21.16 \pm 0.06$ & $2.34 \pm 0.01^{\mathrm{b}}$ & $2.44 \pm 0.09^{b}$ & $3.01 \pm 0.09^{\mathrm{a}}$ & $3.23 \pm 0.31^{\mathrm{a}}$ \\
\hline Lipids (\%) & $1.33 \pm 0.04$ & $60.46 \pm 0.65^{a}$ & $56.53 \pm 0.13^{b}$ & $56.37 \pm 0.09^{b}$ & $55.20 \pm 0.06^{\mathrm{c}}$ \\
\hline $\mathrm{TC}(\%)^{* *}$ & $60.63 \pm 0.45$ & $3.18 \pm 0.75^{\mathrm{c}}$ & $8.45 \pm 0.66^{b}$ & $9.23 \pm 0.80^{b}$ & $15.35 \pm 0.44^{\mathrm{a}}$ \\
\hline $\operatorname{TDF}(\%) * * *$ & $31.19 \pm 0.80$ & 0 & 0.78 & 1.56 & 2.34 \\
\hline Cholesterol (mg/100g) & - & $168.63 \pm 0.52^{\mathrm{a}}$ & $154.81 \pm 0.30^{b}$ & $146.82 \pm 0.72^{c}$ & $141.60 \pm 0.92^{d}$ \\
\hline
\end{tabular}

${ }^{a b c}$ Averages in the same row with the same superscript letters did not differ significantly between themselves by Tukey's test ( $\left.\mathrm{P}<0.05\right)$. Means \pm standard deviation of analyses in triplicate $(n=3)$.

T1 (Standard) 100\% EY; T2 75\% EY and 25\% LCBF; T3 50\% EY and 50\% LCBF; T4 25\% EY and 75\% LCBF.

* Chemical composition of LCBF (Alves et al., 2019).

** Total Carboidrate. Values obtained by difference.

*** Total dietary fiber. Calculated from the content reported in the LCBF and the amount incorporated in the formulations.

ELSHESHETAWY (2013), who evaluated the effect of different concentrations of ginger on the characteristics of mayonnaise and found that the $\mathrm{pH}$ value decreased during the 20 weeks of storage.

The mayonnaise showed no significant difference in terms of Aw (Fig. 1E) between them or in relation to the control. This result showed us that the incorporation of LCBF did not affect the AW values even though the flour has a great water absorption capacity. This result is important because a high water activity could favour microbial growth, lipid oxidation and influence the viscosity parameters of mayonnaise.

During the first 14 days of storage, treatments $\mathrm{T} 1, \mathrm{~T} 2$ and $\mathrm{T} 4$ darkened $\left(\mathrm{L}^{*}\right)$; however, T3 did not change the colour (Table 2). This browning brings a negative aspect to mayonnaise with great impact on the appearance and acceptance of the product (WORRASINCHAI et al., 2006; ELBOSTANY et al., 2011). The values of a* did not vary during storage and did not show significant differences between them. Results for the $b^{*}$ (Table 2) parameter increased over the 30 days of storage. This may have been related to the oxidation process, which tends to increase $b^{*}$ values. According to GARCÍA-ESTEBAN et al. (2004) differences in $b^{*}$ values during storage can be explained by the intensity of the oxidation process that occurs during storage, which tends to increase the yellow colouring of products due to rancidity.

Regarding stability (Table 2), T2 and T3 remained stable and showed no significant difference during storage time, even when compared to the control. One possible reason for the fact that $\mathrm{T} 2$ and T3 do not differ from T1 may have been related to the protein-polysaccharide interaction (egg yolk - LCBF), which significantly reduces the interfacial tension of oil and water, creating a stable emulsion (RAHBARI et al., 2014). However, the T4 treatment showed significant difference from the other treatments during storage. On day 0 its stability showed a marked decrease compared to the other treatments but on 7 it increased and from day 14 it decreased again; the high ratio of bean flour in relation to egg yolk was insufficient to maintain the stability of the mayonnaise. The stability of an emulsion is an important factor because it is associated with the prevention of the coalescence of oil droplets and creaming. The mayonnaises made from bean flour remained stable until the concentration of $50 \%$ egg yolk. Similar results were found in a study by GHOUSH et al. (2008) that developed mayonnaise with the replacement of egg yolk by wheat protein and iota-type carrageenan gum; as the egg yolk content decreased the stability of the emulsion also decreased. 
Table 2 - Rheological parameters $(n$ and $K)$ adjusted by the Ostwald-de-Waelle (Power Law) model, instrumental color parameters $\left(L^{*}, a^{*}\right.$ and $b^{*}$ ) and stability (S) of mayonnaise prepared with different proportions of LCBF to partially replace $\mathrm{EY}$, stored at $4^{\circ} \mathrm{C}$ for 30 days.

\begin{tabular}{|c|c|c|c|c|c|c|}
\hline Treatments & & Day 0 & Day 7 & Day 14 & Day 21 & Day 30 \\
\hline & $\mathrm{T} 1$ & $0.19 \pm 0.02^{\mathrm{cB}}$ & $0.25 \pm 0.02^{\mathrm{aAB}}$ & $0.26 \pm 0.01^{\mathrm{aB}}$ & $0.27 \pm 0.01^{\mathrm{aAB}}$ & $0.28 \pm 0.02^{\mathrm{aA}}$ \\
\hline & $\mathrm{T} 2$ & $0.24 \pm 0.02^{\mathrm{cA}}$ & $0.25 \pm 0.01^{\mathrm{cAB}}$ & $0.27 \pm 0.00^{\mathrm{bAB}}$ & $0.29 \pm 0.01^{\mathrm{aA}}$ & $0.29 \pm 0.00^{\mathrm{abA}}$ \\
\hline \multirow[t]{4}{*}{$n$} & $\mathrm{~T} 3$ & $0.21 \pm 0.01^{\mathrm{cB}}$ & $0.23 \pm 0.01^{\mathrm{bB}}$ & $0.27 \pm 0.00^{\mathrm{aAB}}$ & $0.26 \pm 0.00^{\mathrm{aAB}}$ & $0.27 \pm 0.00^{\mathrm{aB}}$ \\
\hline & $\mathrm{T} 4$ & $0.26 \pm 0.01^{\mathrm{aA}}$ & $0.26 \pm 0.01^{\mathrm{aA}}$ & $0.28 \pm 0.01^{\mathrm{aA}}$ & $0.28 \pm 0.00^{\mathrm{aA}}$ & $0.28 \pm 0.01^{\mathrm{aA}}$ \\
\hline & $\mathrm{T} 1$ & $5.51 \pm 0.02^{\mathrm{aA}}$ & $5.32 \pm 0.08^{\mathrm{abA}}$ & $5.26 \pm 0.08^{\mathrm{abA}}$ & $5.23 \pm 0.04^{\mathrm{abA}}$ & $5.17 \pm 0.08^{\mathrm{abA}}$ \\
\hline & $\mathrm{T} 2$ & $5.41 \pm 0.03^{\mathrm{aB}}$ & $5.32 \pm 0.03^{\mathrm{abA}}$ & $5.24 \pm 0.03^{\mathrm{bcA}}$ & $5.17 \pm 0.04^{\mathrm{cA}}$ & $5.15 \pm 0.02^{\mathrm{cA}}$ \\
\hline \multirow[t]{4}{*}{$K($ Pa.sn $)$} & $\mathrm{T} 3$ & $5.52 \pm 0.01^{\mathrm{aA}}$ & $5.40 \pm 0.01^{\mathrm{bA}}$ & $5.31 \pm 0.01^{\mathrm{cA}}$ & $5.25 \pm 0.04^{\mathrm{cdA}}$ & $5.19 \pm 0.00^{\mathrm{dA}}$ \\
\hline & $\mathrm{T} 4$ & $5.38 \pm 0.03^{\mathrm{aB}}$ & $5.34 \pm 0.01^{\mathrm{aA}}$ & $5.26 \pm 0.01^{\mathrm{bA}}$ & $5.21 \pm 0.01^{\mathrm{bcA}}$ & $5.17 \pm 0.01^{\mathrm{acA}}$ \\
\hline & $\mathrm{T} 1$ & $85.75 \pm 0.52^{\mathrm{aA}}$ & $85.85 \pm 0.25^{\mathrm{aA}}$ & $85.19 \pm 0.46^{\mathrm{aA}}$ & $82.53 \pm 0.36^{\mathrm{bA}}$ & $81.98 \pm 0.44^{\mathrm{bA}}$ \\
\hline & $\mathrm{T} 2$ & $82.97 \pm 0.36^{\mathrm{aB}}$ & $82.92 \pm 0.65^{\mathrm{aB}}$ & $82.49 \pm 0.15^{\mathrm{aB}}$ & $80.50 \pm 0.75^{\mathrm{bB}}$ & $80.73 \pm 0.78^{\mathrm{bAB}}$ \\
\hline \multirow[t]{4}{*}{$\mathrm{L}^{*}$} & $\mathrm{~T} 3$ & $82.01 \pm 0.11^{\mathrm{bB}}$ & $81.80 \pm 0.34^{\mathrm{abB}}$ & $80.18 \pm 1.25^{\mathrm{aC}}$ & $80.02 \pm 1.00^{\mathrm{aB}}$ & $80.18 \pm 0.72^{\mathrm{aB}}$ \\
\hline & $\mathrm{T} 4$ & $79.09 \pm 0.09^{\mathrm{aC}}$ & $79.12 \pm 0.58^{\mathrm{aC}}$ & $77.44 \pm 0.01^{\mathrm{bD}}$ & $76.30 \pm 0.61^{\mathrm{cC}}$ & $73.20 \pm 0.62^{\mathrm{cC}}$ \\
\hline & $\mathrm{T} 1$ & $8.39 \pm 0.06^{\mathrm{aA}}$ & $8.53 \pm 0.32^{\mathrm{aA}}$ & $8.23 \pm 0.62^{\mathrm{aA}}$ & $8.23 \pm 0.07^{\mathrm{aA}}$ & $8.13 \pm 0.11^{\mathrm{aA}}$ \\
\hline & $\mathrm{T} 2$ & $7.54 \pm 0.40^{\mathrm{aAB}}$ & $7.58 \pm 0.15^{\mathrm{aB}}$ & $7.56 \pm 0.16^{\mathrm{aAB}}$ & $7.44 \pm 0.05^{\mathrm{aB}}$ & $7.37 \pm 0.07^{\mathrm{aB}}$ \\
\hline \multirow[t]{4}{*}{$a^{*}$} & $\mathrm{~T} 3$ & $7.51 \pm 0.16^{\mathrm{aAB}}$ & $7.52 \pm 0.04^{\mathrm{aB}}$ & $7.29 \pm 0.22^{\mathrm{aAB}}$ & $7.28 \pm 0.29^{\mathrm{aB}}$ & $7.69 \pm 0.18^{\mathrm{aB}}$ \\
\hline & $\mathrm{T} 4$ & $6.72 \pm 0.31^{\mathrm{aB}}$ & $6.71 \pm 0.14^{\mathrm{aC}}$ & $6.49 \pm 0.03^{\mathrm{aC}}$ & $6.65 \pm 0.25^{\mathrm{aB}}$ & $6.29 \pm 0.32^{\mathrm{aC}}$ \\
\hline & $\mathrm{T} 1$ & $38.74 \pm 0.46^{\mathrm{cA}}$ & $40.06 \pm 0.59^{\mathrm{bcA}}$ & $40.65 \pm 0.75^{\mathrm{bcA}}$ & $41.27 \pm 0.14^{\mathrm{bA}}$ & $43.98 \pm 0.52^{\mathrm{aA}}$ \\
\hline & $\mathrm{T} 2$ & $37.35 \pm 0.52^{\mathrm{bA}}$ & $36.77 \pm 0.37^{\mathrm{bcB}}$ & $37.30 \pm 0.33^{\mathrm{bAB}}$ & $40.07 \pm 0.16^{\mathrm{aB}}$ & $40.95 \pm 0.61^{\mathrm{aB}}$ \\
\hline \multirow[t]{4}{*}{$b^{*}$} & $\mathrm{~T} 3$ & $35.25 \pm 0.16^{\mathrm{cB}}$ & $36.77 \pm 0.66^{\mathrm{bcB}}$ & $37.31 \pm 0.66^{\mathrm{bB}}$ & $40.07 \pm 0.40^{\mathrm{aB}}$ & $40.95 \pm 0.38^{\mathrm{aB}}$ \\
\hline & $\mathrm{T} 4$ & $35.66 \pm 0.43^{\mathrm{bB}}$ & $37.12 \pm 0.51^{\mathrm{bB}}$ & $40.40 \pm 0.51^{\mathrm{aA}}$ & $41.33 \pm 0.37^{\mathrm{aA}}$ & $41.17 \pm 0.41^{\mathrm{aB}}$ \\
\hline & $\mathrm{T} 1$ & $99.91 \pm 0.01^{\mathrm{aA}}$ & $99.85 \pm 0.07^{\mathrm{aA}}$ & $99.92 \pm 0.00^{\mathrm{aA}}$ & $99.94 \pm 0.00^{\mathrm{aA}}$ & $99.91 \pm 0.02^{\mathrm{aA}}$ \\
\hline & $\mathrm{T} 2$ & $99.91 \pm 0.02^{\mathrm{aA}}$ & $99.23 \pm 0.01^{\mathrm{aA}}$ & $99.92 \pm 0.01^{\mathrm{aA}}$ & $99.91 \pm 0.02^{\mathrm{aA}}$ & $99.90 \pm 0.06^{\mathrm{aA}}$ \\
\hline \multirow[t]{2}{*}{ S (\%) } & $\mathrm{T} 3$ & $99.71 \pm 0.02^{\mathrm{aA}}$ & $99.23 \pm 0.67^{\mathrm{aA}}$ & $99.92 \pm 0.01^{\mathrm{aA}}$ & $99.91 \pm 0.05^{\mathrm{aA}}$ & $99.93 \pm 0.00^{\mathrm{aA}}$ \\
\hline & $\mathrm{T} 4$ & $67.54 \pm 0.35^{\mathrm{dB}}$ & $95.60 \pm 0.77^{\mathrm{aB}}$ & $89.36 \pm 0.07^{\mathrm{bB}}$ & $83.21 \pm 0.51^{\mathrm{cB}}$ & $64.34 \pm 0.01^{\mathrm{eB}}$ \\
\hline
\end{tabular}

${ }^{a b c}$ Averages in the same row with the same superscript letters did not differ significantly by Tukey's test $(\mathrm{P}<0.05){ }^{\mathrm{AB}}$ Averages in the same column with the same superscript letters did not differ significantly by Tukey's test $(\mathrm{P}<0.05)$. Means \pm standard deviation of analyses in triplicate (n=3). T1 (Standard) 100\% EY; T2 75\% EY and 25\% LCBF; T3 50\% EY and 50\% LCBF; T4 25\% EY and 75\% LCBF.

\section{CONCLUSION}

The partial replacement of EY by LCBF improved the nutritional characteristics of the mayonnaises by providing increased protein content and decreased cholesterol and lipid content. The obtained mayonnaise continued to exhibit pseudoplastic behaviour being a non-Newtonian fluid 
characteristic of mayonnaise. The substitution of the EY can be carried out in quantities of up to $50 \%$ without prejudice to the mayonnaise, the formulation with $50 \%$ substitution presented the best viscosity and remained stable, similar to the standard mayonnaise. Another advantage of replacing the EY with LCBF is the low cost and high nutritional value.

\section{ACKNOWLEDGMENTS}

We thank the Coordenação de Aperfeiçoamento de Pessoal de Nível Superior (CAPES) - Finance Code 001.

\section{DECLARTION OF CONFLICT OF INTERESTS}

The authors declare no conflict of interest. The founding sponsors had no role in the design of the study; in the collection, analyses, or interpretation of data; in the writing of the manuscript, and in the decision to publish the results.

\section{AUTHORS' CONTRIBUTIONS}

The authors contributed equally to the manuscript.

\section{REFERENCES}

AGUILERA, Y. et al. Bioactive phenolic compounds and functional properties of dehydrated bean flours. Food Research International, v. 44, n. 3, p. 774-780, 2011. Available from: $<$ https://doi.org/10.1016/j.foodres.2011.01.004>. Accessed: Dec. 05, 2018. doi: 10.1016/j.foodres.2011.01.004.

ALVES, J.S. et al. Chemical characterization, bioactive compounds, and functional technological properties of flour from two cultivars of landrace common beans (Phaseolus vulgaris L.). International Food Research Journal, v. 26, n. 2, p. 565-572, 2019. Available from: $\quad<$ http://www.ifrj.upm.edu.my/26\%20(02)\%202019/(22)>. Accessed: May. 14, 2019.

AOAC. Association of Official Analytical Chemists. Official methods of analysis of the AOAC international. $18^{\text {th }}$ ed. Arlington: AOAC, 2005.

BRASIL. Agência Nacional de Vigilância Sanitária. Resolução RDC $\mathrm{n}^{\circ} 276$, de 22 de setembro de 2005. Aprova o Regulamento Técnico para Especiarias, Temperos e Molhos. Diário Oficial da União, Brasília, 2005. Available from: <https://www.gov.br/agricultura/ pt-br/assuntos/inspecao/produtos-vegetal/legislacao-1/biblioteca-denormas-vinhos-e-bebidas/resolucao-rdc-no-276-de-22-de-setembrode-2005.pdf/view>. Accessed: Nov.. 14, 2020.

CARDADOR-MARTÍNEZ, A. et al. Antioxidant activity in common beans (Phaseolus vulgaris L.). Journal of Agricultural Food Chemistry, v. 50, n. 24, p. 6975-6980, 2002. Available from: <https://doi.org/10.1021/jf020296n>. Accessed: Jan. 25, 2019. doi: 10.1021/jf020296n.

EL-BOSTANY, A.N. et al. Development of light mayonnaise formula using carbohydrate-based fat replacement. Australian Journal of Basic and Applied Sciences, v. 5, n. 9, p. 673-682, 2011. Available from: <http://www.ajbasweb.com/old/ajbas/2011/ September-2011/673-682.pdf>. Accessed: Feb. 14, 2019
GARCÍA- ESTEBAN, M. et al. Comparison of modified atmosphere packaging and vacuum packaging for long period storage of drycured ham: effects on color, texture and microbiological quality. Meat Science, v. 67, n. 1, p. 57-63, 2004. Available from: <https:// doi.org/10.1016/j.meatsci.2003.09.005>. Accessed: Feb. 12, 2019. doi: 10.1016/j.meatsci.2003.09.005.

GHOUSH, M.A. et al. Formulation and fuzzy modeling of emulsion stability and viscosity of a gum-protein emulsifier in a model mayonnaise system. Journal of Food Engineering, v. 84, n. 2, p. 348-357, 2008. Available from: <https://doi.org/10.1016/j. jfoodeng.2007.05.025>. Accessed: Feb. 11, 2019. doi: 10.1016/j. jfoodeng.2007.05.025.

IBARZ, A.; BARBOSA-CÁNOVAS, G.V. Operaciones unitarias en la ingeniería de alimentos. In: _. Reología de productos alimentarios. Spain: Mundi Prensa, 2011. p.129-180.

JUSZCZAK, L. et al. Sensory and rheological properties of Polish commercial mayonnaise. Nahrung/Food, v. 47, n. 4, p. $232-235,2003$. Available from: <https://doi.org/10.1002/ food.200390054>. Accessed: Dec. 01, 2020. doi: 10.1002/ food. 200390054

KISHK, Y.F.M.; ELSHESHETAWY, H.E. Effect of ginger powder on the mayonnaise oxidative stability, rheological measurements and sensory characteristics. Annals of Agricultural Science, v. 58, n. 2, p. 213-220, 2013. Available from: <https://doi.org/10.1016/j.aoas.2013.07.016> Accessed: Dec. 01, 2020. doi: 10.1016/j.aoas.2013.07.016.

LONDERO, P.M. et al. Development of functional beef meatball using landrace common bean flour as a substitute for meat and textured soy protein. International Food Research Journal, v. 22, n. 5, p. 2041-2049, 2015. Available from: <http://www.ifrj.upm.edu.my/22\%20(05)\%202015/(43)>. Accessed: Jan. 20, 2019.

MA, L.; BARBOSA-CANOVAS. G. V. (1995). Rheological characterization of mayonnaise. Part II: flow and viscoelastic properties at different oil and xanthan gum concentration. Journal of Food Engineering, v. 25, n. 3, p. 409-425, 1995. Available from: <https://doi.org/ 10.1016/02608774(94)00010-7>. Accessed: Dec. 01, 2020.

MA, Z. et al. Techno-functional characterization of salad dressing emulsions supplemented with pea, lentil and chickpea flours. Journal of the Science of Food and Agriculture, v. 96, n. 3, p. 837-847, 2015. Available from: <https://doi. org/10.1002/jsfa.7156>. Accessed: Feb. 20, 2019.

MATHIAS, T.R.S. et al. Avaliação do comportamento reológico de diferentes iogurtes comerciais. Brazilian Journal of Food Technology, v. 16, n. 1,p. 12-20,2013. Available from: < https:// doi.org/10.1590/S1981-67232013005000004>. Accessed: Nov. 15, 2020. doi: 10.1590/S1981-67232013005000004.

McClements, D.J. Food emulsions: principles, practices, and techniques. Boca Raton: CRC press, 2016. 3th.

MUN, S. et al. Development of reduced-fat mayonnaise using $4 \alpha$ GTase-modified rice starch and xanthan gum. International Journal of Biological Macromolecules, v. 44, n. 5, p. 400-407, 2009. Available from: <https://doi.org/10.1016/j. ijbiomac.2009.02.008>. Accessed: May. 12, 2019. doi: 10.1016/j. ijbiomac.2009.02.008. 
NIKZADE, V. et al. Optimization of low-cholesterol-low-fat mayonnaise formulation: effect of using soy milk and some stabilizer by a mixture design approach. Food Hydrocolloids, v. 28, n. 2, p. 344-352, 2012. Available from: <https://doi. org/10.1016/j.foodhyd.2011.12.023> Accessed: Dec. 10, 2018. doi: 10.1016/j.foodhyd.2011.12.023.

PEREIRA, T. et al. Diversidade no teor de nutrientes em grãos de feijão crioulo no Estado de Santa Catarina. Acta Scientiarum. Agronomy, v. 33, n. 3, p. 477-485, 2011. Available from: <http:// www.scielo.br/scielo.php? script $=$ sci arttext\&pid $=$ S 1807 $86212011000300014 \& \operatorname{lng}=\mathrm{en} \& \mathrm{nrm}=\mathrm{iso}>$ Accessed: Nov. 29, 2020 .

PIZZOLAnTE, C. C. O ovo e o mito do colesterol. Pesquisa \& Tecnologia, v. 9, n. 1, 2012. Available from: http://www. ovosrs.com.br/_files/view.php/load/pasta/9/579a1056adbfd.pdf> Accessed: Dec. 12, 2018.

RAHBARI, M. et al. A mixture design approach to optimizing low cholesterol mayonnaise formulation prepared with wheat germ protein isolate. Journal of Food Science and Technology, v. 52, n. 6, p. 3383-3393, 2014. Available from: $<$ https://doi.org/10.1007/ s13197-014-1389-4>. Accessed: Jan, 14, 2019. doi: 10.1007/ s13197-014-1389-4.

RAMÍREZ-JIMÉNEZ. A.K. et al. Functional properties and sensory value of snack bars added with common bean flour as a source of bioactive compounds. LWT - Food Science and Technology, v. 89, p. 674-680, 2018. Available from: <https://doi. org/10.1016/j.lwt.2017.11.043>. Accessed: Nov. 29, 2020. doi: 10.1016/j.lwt.2017.11.043.

RISCARDO, M.A. et al. Influence of composition of emulsifier blends on the rheological properties of salad dressing-type emulsions. Food Science and Technology International, v. 9, n. 1, p. 53-63, 2003. Available from: $<$ https://doi.org/10.1177/1082013203009001 008>. Acessed: Jan. 10, 2019. doi: 10.1177/1082013203009001008.

SALDANHA, T. et al. Avaliação comparativa entre dois métodos para determinação do colesterol em carnes e leite. Revista Ciência e Tecnologia dos Alimentos, v. 24, n. 1, p. 109-113, 2004. Available from: <https://doi.org/10.1590/S0101-20612004000100020>. Accessed: Jan. 07, 2019. doi:10.1590/S0101-20612004000100020.

WANI, I.A. et al. Physico-chemical and functional properties of flours from Indian kidney bean (Phaseolus vulgaris L.) cultivars. LWT - Food Science and Technology, v. 53, n. 1, p. 278-284, 2013. Available from: <https://doi.org/10.1016/j.lwt.2013.02.006>. Accessed: Jan. 30, 2019. doi: 10.1016/j.lwt.2013.02.006.

WORRASINCHAI, S. et al. $\beta$-Glucan prepared from spent brewer's yeast as a fat replacer in mayonnaise. Food Hydrocolloids, v. 20, n. 1, p. 68-78, 2006. Available from: <https://doi.org/10.1016/j. foodhyd.2005.03.005>. Accessed: Feb. 14, 2019. doi: 10.1016/j. foodhyd.2005.03.005. 